\title{
Arte e Tecnologia: um diálogo
}

Segundo o artista plástico Nivaldo Carneiro, a utilização de compósitos à base de polipropileno e fibras de madeira, material desenvolvido no IMA/UFRJ, em esculturas, pode resultar em formas diversificadas e muito expressivas. Além da leveza do material que permite seu uso em peças de grande porte, o que mais o impressionou foi o resultado em termos de textura. $\mathrm{O}$ movimento circular característico do polímero proveniente da matriz da extrusora conferiu uma textura ines-

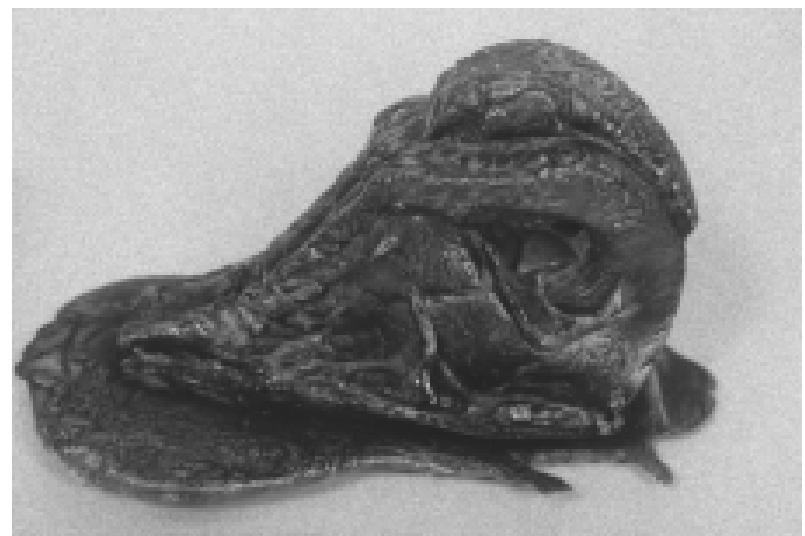

Figura 1. Foto da escultura feita em compósito à base de polipropileno e fibras de madeira com pátina de alumínio

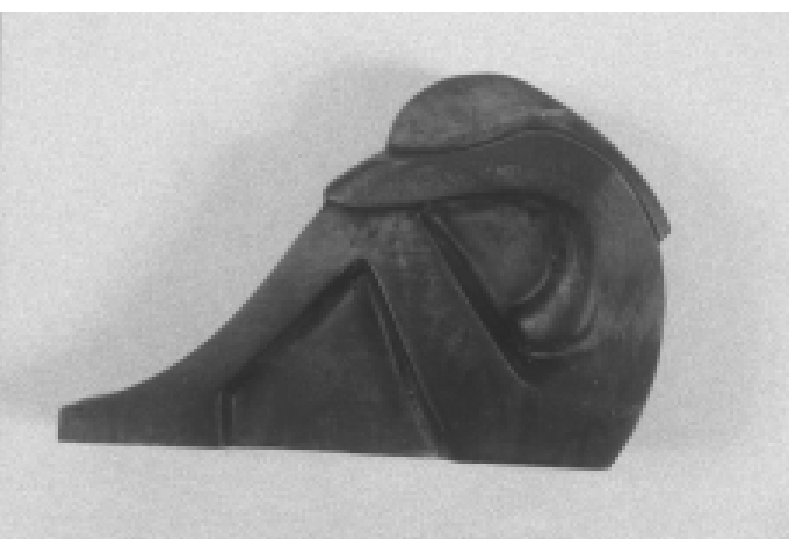

Figura 2. Foto da escultura feita em resina de poliéster com pátina de cobre

perada, sugerindo a forma como o material foi posto em camadas no molde. Embora não costume dar títulos a suas esculturas, batizou como "Beleza Orgânica", as peças de compósito tratadas ou não com uma pátina de metal (Figura 1). Em relação à mesma escultura feita em resina de poliéster (Figura 2), material normalmen- te utilizado, Nivaldo percebeu que as peças em compósito são únicas, orgânicas e vibrantes.

Um outro material muito apreciado para utilização no Curso de Escultura onde Nivaldo é professor, é o "Gesseca", gesso reforçado com polímero. O material desenvolvido também no IMA, é de fácil utilização. Em vez de água, uma solução aquosa de polímero hidrossolúvel é misturada ao gesso, tornando-o cinco vezes mais resistente.

No ano que vem Nivaldo planeja fazer esculturas em PET reciclado de garrafas de refrigerante utilizando uma extrusora do IMA. As características peculiares de fluidez do PET permitem seu uso em peças grandes, sem necessidade de aquecimento do molde. A utilização do polímero reciclado contribui para a preservação ambiental e a resposta em termos visuais da escultura é uma prazerosa incógnita. As possibilidades de aplicação de polímeros e compósitos em esculturas são ilimitadas. Além da utilização dos diferentes tipos de plásticos, esculturas podem ser montadas a partir de extrusados frios (macarrão), extrusados quentes moldados com auxílio de espátula de teflon ou por meio de moldes.

Além de divulgar a utilização de compósitos e polímeros em esculturas, o grupo tem outros objetivos. A maior integração dos vários setores e profissionais da Universidade Federal pode gerar trabalhos de cunho social e tecnológico importantes. Além disso, essa integração é uma forma de fortalecer a Universidade Federal com a valorização por igual das áreas artística, tecnológica e humana. Está sendo montada uma home page onde uma figura tridimensional de "Beleza Orgânica" simboliza esse desafio. No interior desta figura será montada uma rede onde cada ponto vai representar o link com os vários setores da Universidade. O grupo acredita que desta forma será mais fácil a parceria e a troca de talentos entre diferentes profissionais.

Nivaldo Carneiro Escola de Belas Artes, Curso de Escultura/UFRJ;

Thais H.S. Costa e Elisabeth E. Monteiro Instituto de Macromoléculas Professora Eloisa Mano/UFRJ, C.P.68525, CEP: 21945-970, Rio de Janeiro, RJ. 
